\title{
GENETIC STUDIES OF FAMILIAL AMYLOID POLY- NEUROPATHY IN THE ARAO DISTRICT OF JAPAN
}

\section{ANALYSIS OF AMYLOID FIBRIL PROTEIN}

\author{
Masao UejI, ${ }^{1}$ Tomokazu Suzuki, ${ }^{1, *}$ Sadayoshi Higa, ${ }^{1}$ Saburo Sakoda, ${ }^{1}$ \\ Susumu Kishimoto, ${ }^{1}$ Koiti Titani, ${ }^{2}$ Koji Takio, ${ }^{2, * * *}$ \\ Akira HAYASHI, ${ }^{3}$ Yoshio TAKabA, ${ }^{4}$ and Akira NAKAJIMA ${ }^{5}$ \\ ${ }^{1}$ The Third Department of Internal Medicine, Osaka University Hospital, \\ Osaka 553, Japan \\ 2 Department of Biochemistry, University of Washington, \\ Seattle, Washington 98195, U.S.A. \\ ${ }^{3}$ Osaka Medical Center and Research Institute for Maternal and \\ Child Health, Osaka 590-02, Japan \\ ${ }^{4}$ The Arao City Hospital, Kumamoto 864, Japan \\ ${ }^{5}$ The Nakajima Medical Clinic, Kumamoto 864, Japan
}

\begin{abstract}
Summary The predominant amyloid fibril proteins isolated from kidneys of four patients with familial amyloid polyneuropathy (FAP) from three genealogically independent families in the Arao district of Japan have been analysed for the primary structure. Irrespective of the patient or the family, the major protein isolated consisted of some components of a prealbumin variant, in which an amino acid substitution of methionine for valine occurred at position 30 , with a heterogenous $\mathrm{N}$-terminus caused by some degradation of $\mathrm{N}$-terminal amino acids in the prealbumin subunit. It is likely that this prealbumin variant is concerned with the process of this hereditary disease, rather than being a genetic polymorphism of prealbumin. Further, we conclude that the FAP families of the Arao focus may have a common ancestor.
\end{abstract}

\section{INTRODUCTION}

Type 1 familial amyloid polyneuropathy (FAP) is an autosomal dominant hereditary disease characterized by amyloid deposit and polyneuropathy accompanied with severe autonomic dysfunction (Glenner et al., 1978). FAP has been reported from Portugal (Andrade, 1952), Japan (Araki et al., 1968; Kito et al., 1973), Sweden (Andersson, 1976) and a few other countries. Our previous gene-

Received June 21, 1984

* To whom correspondence and reprint requests should be addressed. ** Associate of Howard Hughes Medical Institute. 
alogical study revealed that FAP in the Arao district of Japan, first reported by Araki et al. (1968), affects nearly one hundred patients among nine families (Sakoda et al., 1983). Subsequent studies of genetic markers in blood suggested that 3 of 7 families examined in Arao have a common ancestor (Sakoda et al., 1984).

The amyloid fibril protein in FAP of Portuguese origin was demonstrated to be a 14,000-dalton protein antigenically related to serum prealbumin (Costa et al., 1978). Subsequently, biochemical and immunochemical analyses on amyloid fibrils from FAP patients of Japanese (Tawara et al., 1981; Shoji and Okano, 1981) and Swedish (Benson, 1981; Skinner and Cohen, 1981) origin supported this finding. Most recently, a prealbumin variant ( $49 \mathrm{Thr} \rightarrow$ Gly) has been identified as the amyloid fibril protein from a patient in a Jewish family afflicted with FAP (Pras et al., 1983), and a different one (Prealbumin $30 \mathrm{Val} \rightarrow \mathrm{Met}$ ) has been identified from a patient in the Arao focus (Tawara et al., 1983). The latter has also been isolated from the amyloid laden tissues and the serum of an individual with FAP of Swedish origin (Dwulet and Benson, 1983, 1984). However, it remains unknown whether these variants are essential for amyloidogenesis in FAP or whether they only represent polymorphisms of prealbumin (Tawara et al, 1983; Dwulet and Benson, 1983, 1984).

Here, we describe the primary structure of the amyloid fibril protein isolated from four FAP patients, including 2 sibs, among three genealogically independent families in Arao.

\section{MATERIALS AND METHODS}

Materials. Amyloid laden kidneys were obtained at the autopsies of four patients with FAP in the Arao district of Japan. Case 1, T.H., a 47-year-old man, is a member of the U family; case 2, T.Y., a 41 -year-old woman, is a member of the $\mathrm{S}$ family; case 3, O.M., a 51-year-old man, is a member of the $\mathrm{H}$ family; and case 4, T.M., a 46-year-old woman, is a sister of case 3 . The $\mathrm{U}, \mathrm{S}$ and $\mathrm{H}$ families are genealogically independent of one another (Sakoda et al., 1983). Each patient had a typical clinical course of FAP and the diagnosis made by clinical features and family history was confirmed by autopsy. Control analyses were performed on a kidney obtained from a 52-year-old woman who died from a myocardial infarction.

Isolation of amyloid fibrils. Amyloid fibrils were extracted from the kidneys by the method of Pras et al. (1968), lyophilized, and examined by electron microscopy.

Fractionation of amyloid fibril. Eighty $\mathrm{mg}$ of lyophilized amyloid fibrils were dissolved in $3 \mathrm{ml}$ of $6 \mathrm{M}$ guanidine $\mathrm{HCl}(\mathrm{Gdn} \cdot \mathrm{HCl})$ in $0.1 \mathrm{M}$ Tris $\cdot \mathrm{HCl}$ (pH 9.4) containing $0.17 \mathrm{M}$ dithiothreitol, and centrifuged at $100,000 \times g$ for $2 \mathrm{hr}$. The supernatant was applied on a Sephadex G-100 column $(1.5 \times 90 \mathrm{~cm})$ equilibrated with $5 \mathrm{M}$ Gdn. $\mathrm{HCl}$ in $1 \mathrm{M}$ acetic acid (Glenner et al., 1972). Each fraction was pooled, dialyzed against distilled water, and lyophilized. The third peak (P3) was further purified as the major component of amyloid fibril protein. Each $5 \mathrm{mg}$ of P3 material was 
reduced with dithiothretiol (Bio Rad) and S-carboxymethylated with iodoacetic acid (Sigma) in $7 \mathrm{M} \mathrm{Gdn} \cdot \mathrm{HCl}-1.5 \mathrm{M}$ Tris, $\mathrm{pH} 8.6$, by a slight modification of the method of Crestfield et al. (1963). The mixture was then directly loaded on a column $(7.5 \times 600 \mathrm{~mm})$ of UltroPac TSK-G2000 SW with a precolumn $(7.5 \times 70 \mathrm{~mm})(\mathrm{LKB})$ equilibrated with $6 \mathrm{~m}$ Gdn.HCl-0.1 $\mathrm{M}$ sodium phosphate, $\mathrm{pH} 6.0$, and eluted with the same buffer at a flow rate of $1 \mathrm{ml} / \mathrm{min}$. The proteins were recovered by freezedrying after dialysis against water.

Subsequent purification of the major fraction from the gel filtration column was achieved by reversed phase high performance liquid chromatography (HPLC), performed with a Varian 5000 Liquid Chromatograph on a column $(4.1 \times 250 \mathrm{~mm})$ of SynchroPak RP-P (Synchrom) using a trifluoroacetic acid (Pierce)-acetonitrile (Burdick \& Jackson) system (Mahoney and Hermodson, 1980). Each sample was dissolved in $100 \mu 1$ of $6 \mathrm{M} \mathrm{Gdn} \cdot \mathrm{HCl}$ and loaded on the column equilibrated with $0.1 \%$ trifluoroacetic acid and eluted by increasing concentrations of acetonitrile containing $0.08 \%$ trifluoroacetic acid at room temperature and a flow rate of $2 \mathrm{ml} / \mathrm{min}$. The protein fractions were directly freeze-dried. The major peak was further purified by rechromatography using a shallower gradient of acetonitrile.

Amino acid and sequence analyses. Amyloid protein is resistant to tryptic digestion even after S-carboxymethylation, as is prealbumin (Gonzales and Offord, 1971). Therefore, each purified CM-protein was pretreated with $100 \mu \mathrm{l}$ of $8 \mathrm{M}$ urea-10 $\mathrm{mm} \mathrm{HCl}$ at $37^{\circ} \mathrm{C}$ for $30 \mathrm{~min}$. After the solution was diluted 4-fold with $0.1 \mathrm{M} \mathrm{NH}_{4} \mathrm{HCO}_{3}, \mathrm{pH} 8.0$, TPCK-trypsin (Worthington) (1\% on molar basis) was added; the solution was then incubated at $37^{\circ} \mathrm{C}$ for $2 \mathrm{hr}$. The digest was adjusted to $\mathrm{pH} 1-2$ with $70 \%$ formic acid and injected into a reversed phase HPLC column, SynchroPak RP-P $(4.1 \times 250 \mathrm{~mm})$. CM-Protein was digested with cyanogen bromide (Kodak) in $70 \%$ formic acid at room temperature for $15 \mathrm{hr}$ (Gross, 1967). The lyophilized digest was dissolved in $6 \mathrm{M} \mathrm{Gdn} \cdot \mathrm{HCl}$ and injected into a reversed phase HPLC column.

Amino acid analysis was performed with a Dionex D-500 Amino Acid Analyzer on a $24 \mathrm{hr}$ hydrolyzate of each $1-2 \mathrm{nmol}$ peptide.

Automated sequence analysis was performed with an Applied Biosystems 470A Protein Sequencer on each $1 \mathrm{nmol}$ peptide using a program adapted from Hunkapiller et al. (1983a). Phenylthiohydantoins (PTH) were identified in a semi-quantitative manner by the HPLC system of Hunkapiller and Hood (1983b).

For comparative studies, normal human prealbumin (kindly provided by Dr. Y. Kanda, Nippon Medical School) was also treated by the same procedure as the P3 material.

SDS-polyacrylamide gel electrophoresis. Each protein fraction on the Sephadex G-100 column and the normal human prealbumin were subjected to electrophoresis in $10 \%$ polyacrylamide gels containing $0.1 \%$ sodium dodecyl sulfate by the method of Weber and Osborn (1969). Bovine serum albumin (M.W. 68,000), pepsin (M.W. 
34,000), lysozyme (M.W. 14,300), and cytochrome $c(12,384)$ (Sigma) were used as markers to estimate molecular weight.

Immunologic studies. Antisera against crude amyloid fibrils were raised in rabbits by repeated injections of guanidine-solubilized amyloid fibrils in complete Freund's adjuvant. The antisera thus obtained and antisera to normal human prealbumin were used to characterize fractionated amyloid proteins by double immunodiffusion and immunoelectrophoresis in $1 \%$ agarose gels in barbital buffer, $\mathrm{pH} 8.2$.

Isoelectric focusing. The method used was a modification of that of Righetti and Chillemi (1978). The gel was fixed in 10\% TCA for $24 \mathrm{hr}$ and bathed directly in the staining solution, Coomassie blue R-250 dissolved in alcohol-acetic acid.

\section{RESULTS}

The crude amyloid fibris extracted with distilled water had a typical fibrous structure when viewed under the electron microscope (data not shown). The Sephadex G-100 gel-filtration of the amyloid fibrils from FAP kidney (case 1) gave a void volume peak (P1) with a shoulder (P2) on the descending limbs, plus a retarded peak (P3) (Fig. 1). The amyloid fibrils from case 2, 3 and 4 showed the same elution patterns as those from case 1 (data not shown). Neither P2 nor P3 was obtained from the control kidney (Fig. 1).

On double immunodiffusion, P2 and P3 reacted with an antiserum to the amyloid fibrils (AAS) and the two precipitin lines were completely fused, but P1 and normal kidney fractions showed no reaction (Fig. 2a). These findings indicate that immunologically $\mathrm{P} 2$ and $\mathrm{P} 3$ are amyloid proteins. By immunoelectrophoresis, AAS

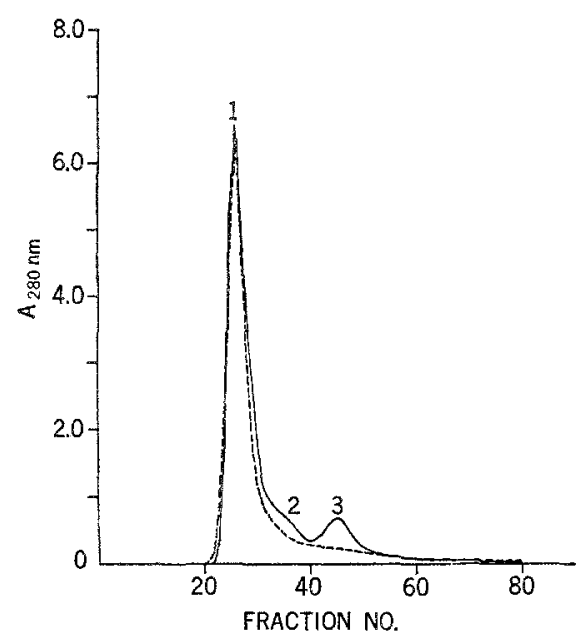

Fig. 1. Chromatogram of amyloid fibrils from case 1 on Sephadex $\mathrm{G}-100$ column (solid line). Chromatogram of normal kidney material (dash line) did not show any retarded peak. Fractions ( $2 \mathrm{ml} /$ tube) were collected. 
gave a single line in the prealbumin range against normal human serum (NHS), prealbumin (PA), and against P3 (Fig. 2b). P3 and prealbumin reacted identically with AAS and with an antiserum to prealbumin (APA) (Fig. 2c).

On SDS-polyacrylamide gel electrophoresis (Fig. 3), P1 demonstrated high molecular bands at the top of the gel. P2 showed the heterogeneous bands at 25,00068,000 daltons. P3 showed an almost single band at 14,000 daltons and its molecular weight was identical to that of prealbumin.

On isoelectric focusing (Fig. 4), the P3 protein of cases 1, 2, and 3 showed the

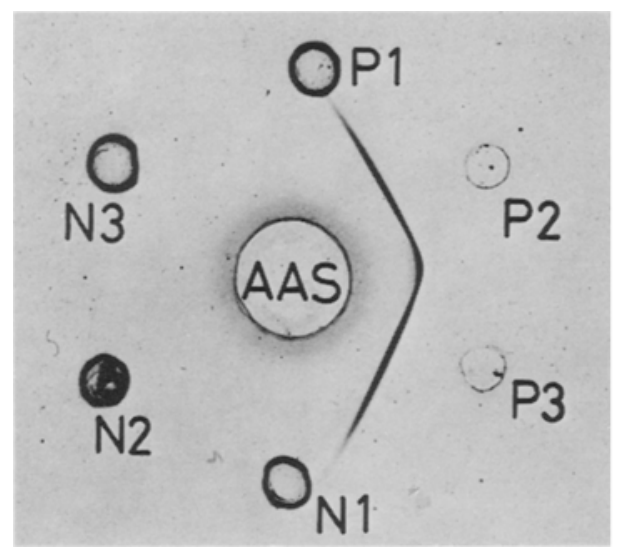

Fig. $2 a$

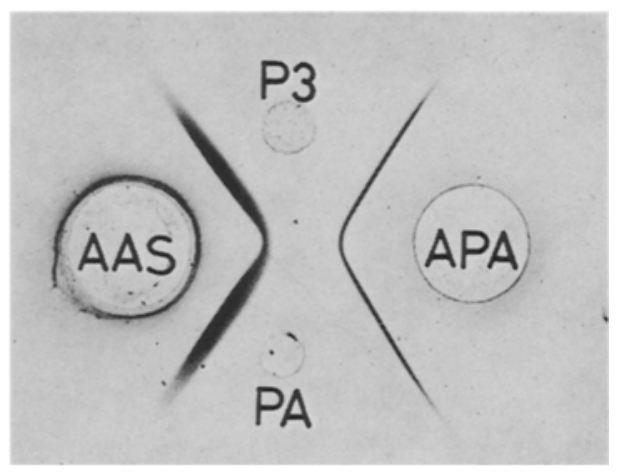

Fig. 2c

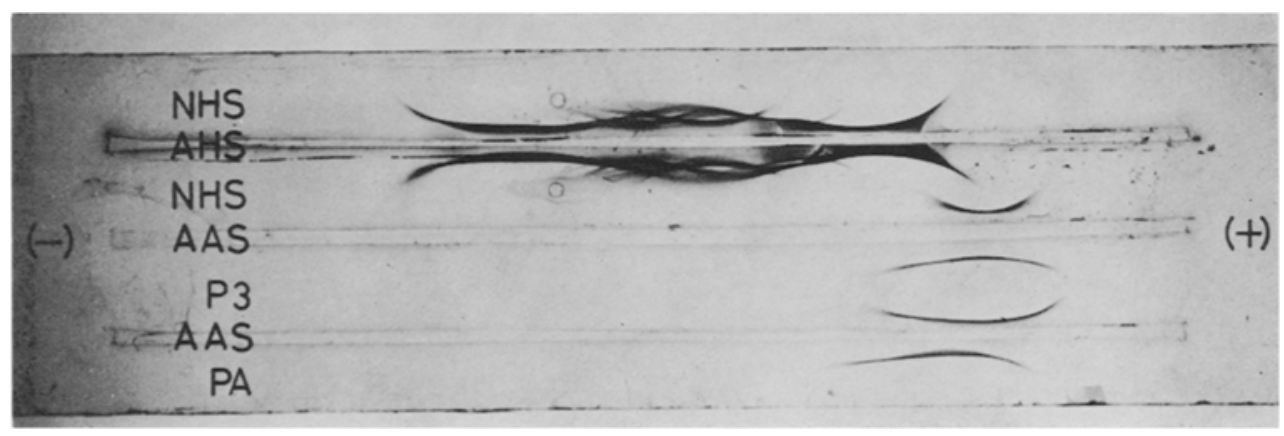

Fig. 2b

Fig. 2a. Double immunodiffusion of fractions from Sephadex G-100 chromatography of amyloid fibrils (P1, P2, P3) and corresponding fractions from Sephadex G-100 chromatography of normal kidney $(\mathrm{N} 1, \mathrm{~N} 2, \mathrm{~N} 3)$ vs. antiserum to amyloid fibrils (AAS).

Fig. 2b. Immunoelectrophoresis of normal human serum (NHS), P3 material, and prealbumin (PA) against antiserum to amyloid fibrils (AAS) (Case 1). AHS, antihuman serum.

Fig. 2c. Immunodiffusion of P3 material (Case 1) and prealbumin (PA) with antiserum to each indicating the immunological identity of proteins. AAS, antiserum to amyloid fibrils; APA, antiserum to prealbumin. 


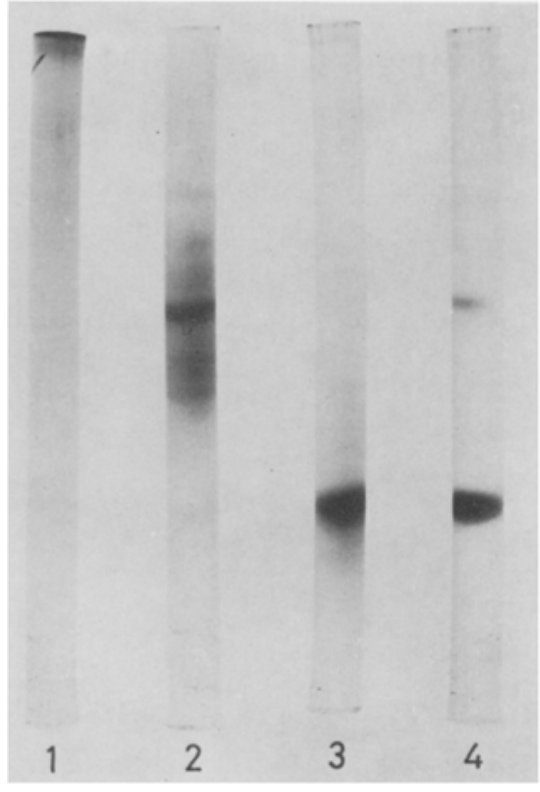

Fig. 3

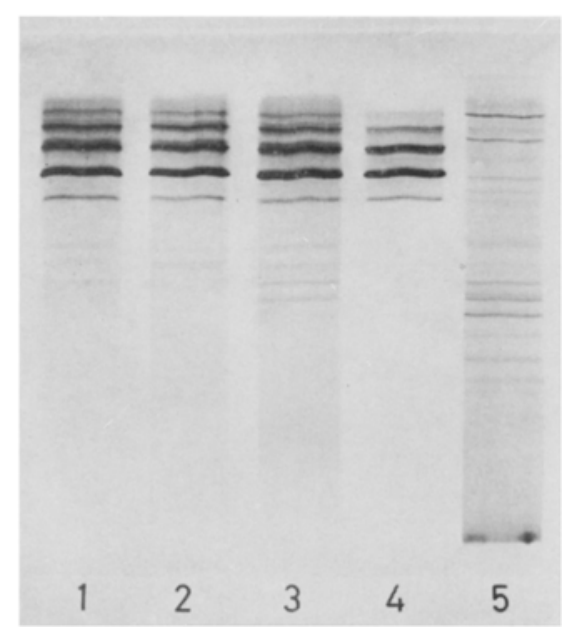

Fig. 4

Fig. 3. SDS-polyacrylamide gel electrophoresis of three peak fractions (P1, P2 and P3) on Sephadex G-100 (Case 1) and prealbumin subunit. 1, P1 material; 2, P2 material; 3, P3 material; 4, prealbumin subunit. P3 shows a band at 14,000 daltons that appears single. The prealbumin subunit also shows a main band at the same position.

Fig. 4. Isoelectric focusing of $\mathrm{P} 3$ material from each case, N3 material from normal kidney, and human prealbumin subunit. Fifty $\mu 1$ of sample $(1 \mathrm{mg} / \mathrm{ml})$ were applied through filter paper strips at the anode (upper) after 40 min prefocusing. 1, P3 material from case $1 ; 2$, P3 material from case $2 ; 3, \mathrm{P} 3$ material from case $3 ; 4$, buman prealbumin subunit; $5, \mathrm{~N} 3$ material from normal kidney.

same major bands in the $\mathrm{pH}$ range $4.0-5.0$; this focusing pattern was very similar to that of PA. The P3 protein of case 4 also had the same focusing pattern (data not shown). Minor heterogeneous bands which are probably impurities were seen in the high $\mathrm{pH}$ range in all cases. Normal kidney fraction (N3) corresponding to P3 merely showed the heterogeneous bands in the $\mathrm{pH}$ range 3.0-10.

Five $\mathrm{mg}$ of $\mathrm{P} 3$ from each of the 4 cases, $1.5 \mathrm{mg}$ of human prealbumin, and $2 \mathrm{mg}$ of N3 from normal kidney were partially purified by size-exclusion HPLC using a TSK G2000 SW column equilibrated with $6 \mathrm{M} \mathrm{Gdn} \cdot \mathrm{HCl}-0.1 \mathrm{~m}$ sodium phosphate buffer, $\mathrm{pH}$ 6.0. The intact protein of each $\mathrm{P} 3$, as well as the prealbumin, showed 2 symmetrical peaks of about $30 \mathrm{~K}$ and $15 \mathrm{~K}$ daltons (about $1: 4$ by peak height) even in the presence of $6 \mathrm{M} \mathrm{Gdn}$. The first peak of $30 \mathrm{~K}$ daltons, however, disappeared and the second peak of $15 \mathrm{~K}$ daltons became relatively higher upon reduction and S-carboxymethylation, indicating that the first peak was the dimer of the second 
generated by partial oxidation of sulfhydryl groups. The major peak of P3 in each case was very similar to that of prealbumin showing the peak maximum of $14-15 \mathrm{~K}$ daltons, but slightly broader than that of prealbumin, whereas $\mathrm{N} 3$ from normal kidney showed a much broader and non-symmetrical peak in the range of 14-16K daltons. The yields of proteins in this step of purification were $3-3.5 \mathrm{mg}$ (4 cases), $1.4 \mathrm{mg}$ (prealbumin) and $1.5 \mathrm{mg}(\mathrm{N} 3)$ after dialysis and lyophilization.

Two and a half $\mathrm{mg}$ of $\mathrm{P} 3$ from each of the 4 cases, $1 \mathrm{mg}$ of prealbumin, and 1 mg of N3, S-carboxymethylated and partially purified by size-exclusion HPLC, were further purified by reversed phase HPLC (Fig. 5). Prealbumin was eluted mainly

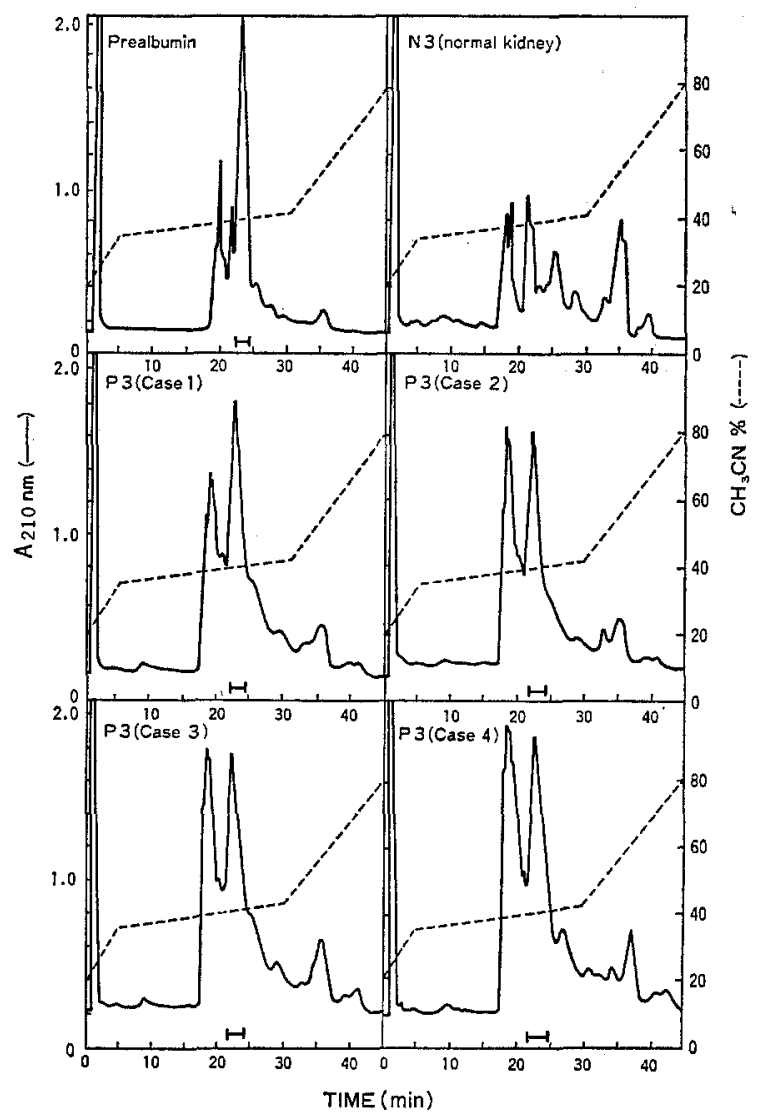

Fig. 5. Purification of P3 (4 cases), prealbumin, and N3 from normal kidney by reversed phase HPLC. $2.5 \mathrm{mg}$ of $\mathrm{P} 3$, partially purified by size-exclusion HPLC after reduction and S-carboxymethylation, was dissolved in $0.5 \mathrm{ml}$ of $6 \mathrm{M} \mathrm{Gdn} \cdot \mathrm{HCl}$, injected into SynchroPak RP-P column equilibrated with $0.1 \%$ trifluoroacetic acid and eluted by increasing concentrations of acetonitrile containing $0.08 \%$ trifluoroacetic acid, as shown by the broken line, at 2 flow rate of $2 \mathrm{ml} / \mathrm{min}$. The major protein fraction was collected as shown by horizontal bar (except for N3) and lypophilized. Each $1 \mathrm{mg}$ of prealbumin and N3 was separated in a similar manner. 
as a single peak, in which about $70 \%$ of the loaded protein was recovered (Table 1), whereas P3 of each case was eluted as about 10 peaks. The predominant peak, however, which was eluted at a very similar place to that of prealbumin, contained $26-40 \%$ of the loaded protein (Table 1). This peak was purified by rechromatog: raphy. N3 from normal kidney yielded as many as 10 peaks without any predominant peak and was not further studied.

Amino acid analysis indicated that the predominant protein of P3 of each case was very similar, but not identical to prealbumin (Table 1), clearly showing a higher content of methionine, i.e., about 2 instead of 1 residue and slightly lower contents of threonine, proline, glycine and valine.

One nmole of the $\mathrm{P} 3$ predominant protein from case 1 was subjected to aminoterminal sequence analysis; there was some heterogeneity of the protein at the amino-terminus (Table 2). The major sequence was revealed to be Thr-Gly-ThrGly--- (about 50\%), but in addition to it, several minor sequences, such as ProThr-Gly-Thr---, Gly-Thr-Gly-Glu--- and Thr-Gly-Glu-Ser---, were also ob-

Table 1. Amino acid residues:a of S-carboxymethylated human prealbumin and $\mathrm{P} 3$ major proteins.

\begin{tabular}{lrrrrr} 
& Prealbumin & Case 1 & Case 2 & Case 3 & Case 4 \\
\hline Cys ${ }^{b}$ & $0.9(1)$ & 0.9 & 1.1 & 1.2 & 0.8 \\
Asx & $7.1(8)$ & 7.2 & 7.1 & 7.5 & 7.0 \\
Thr c & $11.0(12)$ & 9.8 & 9.8 & 10.1 & 9.4 \\
Ser c & $11.1(11)$ & 10.4 & 10.1 & 11.2 & 9.6 \\
Glx & $12.2(12)$ & 11.9 & 11.6 & 11.3 & 11.7 \\
Pro & $8.1(8)$ & 6.3 & 6.7 & 6.4 & 6.8 \\
Gly & $10.3(10)$ & 9.7 & 9.6 & 9.0 & 9.4 \\
Ala & $12.0(12)$ & 12.0 & 12.0 & 12.0 & 12.0 \\
Val d & $11.4(12)$ & 10.5 & 10.9 & 10.2 & 11.0 \\
Met & $0.6(1)$ & 1.8 & 1.7 & 1.8 & 1.7 \\
Iled & $4.5(5)$ & 4.9 & 4.9 & 4.8 & 4.9 \\
Leu & $7.0(7)$ & 7.2 & 6.7 & 6.7 & 7.0 \\
Tyr & $4.4(5)$ & 4.9 & 4.8 & 4.8 & 4.4 \\
Phe & $5.1(5)$ & 4.5 & 4.4 & 4.6 & 4.3 \\
His & $3.7(4)$ & 3.7 & 3.6 & 3.7 & 3.5 \\
Lys & $7.3(8)$ & 7.7 & 7.7 & 7.4 & 7.8 \\
Arg & $4.4(4)$ & 4.5 & 4.6 & 4.8 & 4.8 \\
Trp & N.D. (2) & N.D. & N.D. & N.D. & N.D. \\
\% Yield & 71 & 30 & 26 & 38 & 41 \\
\hline Resid & & & & \\
\hline
\end{tabular}

a Residues per molecule calculated based on amino acid composition assuming 12 residues of alanine per molecule or (in parentheses) from the sequence (Kanda et al., 1974). b Determined as S-carboxymethyl cysteine. " Extraporated to zero-time hydrolysis. a Taken from values of 96-hr acid hydrolysis. e Not determined. 
Table 2. Summary of amino acid sequence analyses of peptides derived from P3 major proteins.

\begin{tabular}{|c|c|}
\hline & Case 1 \\
\hline \multirow{4}{*}{$\begin{array}{l}\text { Amino-terminus of } \\
\text { the whole protein }\end{array}$} & Pro-Thr-Gly-Thr-Gly-Glu-Ser-Lys--- $(5-10 \%)^{\mathrm{a}}$ \\
\hline & Thr-Gly-Thr-Gly-Glu-Ser-Lys--- $(50 \%)$ \\
\hline & Gly-Thr-Gly-Glu-Ser-Lys--- $(10 \%)$ \\
\hline & Thr-Gly-Glu-Ser-Lys--- $(20 \%)$ \\
\hline T1' (Residues 3-15) & Thr-Gly-Thr-Gly-Glu-Ser-Lys--- $(60 \%)^{\mathrm{a}}$ \\
\hline \multirow[t]{2}{*}{ CB1 (Residues 3-13) } & Thr-Gly-Thr-Gly-Glu-Ser-Lys-Cys--- $(60 \%)^{\mathrm{a}}$ \\
\hline & Thr-Gly-Glu-Ser-Lys-Cys--- $(20 \%)$ \\
\hline T3' (Residues 22-34) & Gly-Ser-Pro-Ala-Ile-Asn-Val-Ala-Met-His-Val-Phe-Arg \\
\hline \multirow[t]{2}{*}{ T7 (Residues 49-76) } & $\begin{array}{l}\text { Thr-Ser-Glu-Ser-Gly-Glu-Leu-His-Gly-Leu-Thr-Thr-Glu-Glu-Glu- } \\
\text { Phe-Val-Glu-Gly-Ile-Tyr-Lys-Val-Glu-Ile-Asp-Thr-Lys }\end{array}$ \\
\hline & Case 2 \\
\hline \multirow[t]{2}{*}{ T3' (Residues 22-34) } & Gly-Ser-Pro-Ala-Ile-Asn-Val-Ala-Met-His-Val-Phe-Arg \\
\hline & Case 3 \\
\hline \multirow[t]{2}{*}{ T3' (Residues 22-34) } & Gly-Ser-Pro-Ala-Ile-Asn-Val-Ala-Met-His-Val-Phe-Arg \\
\hline & Case 4 \\
\hline T1' (Residues 3-15) & Thr-Gly-Thr-Gly-Glu-Ser-Lys- - $(60 \%)^{2}$ \\
\hline T3' (Residues 22-34) & Gly-Ser-Pro-Ala-Ile-Asn-Val-Ala-Met-His-Val-Phe-Arg \\
\hline
\end{tabular}

a Relative amounts of sequences were estimated by those of PTH-Glu at cycles 3, 4, 5 and 6 and/or PTH-Lys cycles 5, 6, 7 and 8 .

served. The minor sequences were probably generated by digestion with aminopeptidase-like enzyme. Similar heterogeneity at the amino-terminus of the protein was also observed in 3 other cases.

To identify further the structural differences between P3 and prealbumin, tryptic peptides of each P3 predominant protein from the 4 cases were compared with those of prealbumin of known primary structure (Kanda et al., 1974) by reversed phase HPLC. Since the P3 protein, as well as prealbumin, was resistant to tryptic digestion even after S-carboxymethylation, the protein was denatured in $8 \mathrm{M}$ urea and then digested with trypsin as described in "METHODs." Although only the HPLC chromatogram of case 1 is shown in Fig. 6, identical chromatograms were obtained in the 3 other cases, indicating that the primary structure of the P3 predominant protein from each of the 4 cases is essentially identical.

Three different tryptic ( $T$ ) peptides were identified by comparing the two peptide maps (Fig. 6). As predicted from the analysis of the whole protein, peptide $\mathrm{T} 1$ of prealbumin derived from the amino-terminus is missing in P3. Instead, $\mathrm{T} 1^{\prime}$ with slightly shorter retension time than T1 was isolated from P3. Sequence analysis of the peptide 'T1' $(1 \mathrm{nmol})$ yielded the major 'sequence of Thr-Gly-Thr-GlyGlu-Ser-Lys--- (Table 2), which appeared to derive from the amino-terminus of the protein (residues $3-15$ ). T3 and $\mathrm{T} 4$ of prealbumin appear to be replaced by 


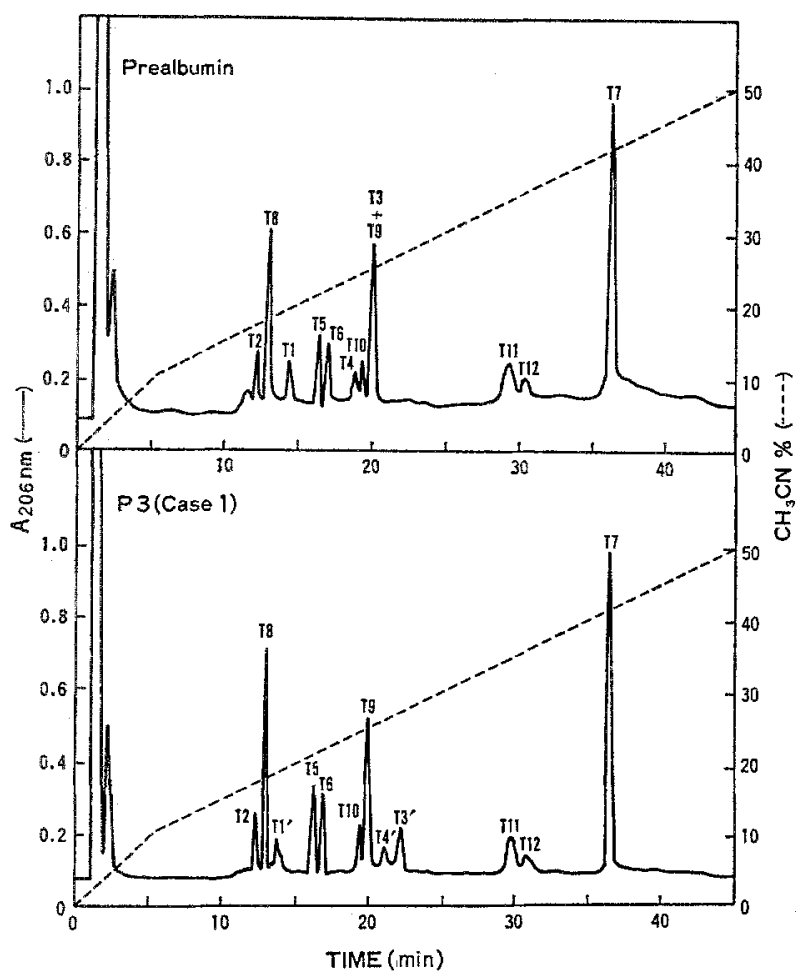

Fig. 6. Separation of tryptic peptides of prealbumin and the P3 predominant protein (Case 1) by reversed phase HPLC. Each $20 \mathrm{nmol}$ of the protein was digested with trypsin as described in "METHODs" and was separated by reversed phase HPLC in a similar manner to that shown in Fig. 5 after acidification with formic acid. $\mathrm{T} 3$ and $\mathrm{T} 9$ of prealbumin were further separated by rechromatography using a shallower gradient of acetonitrile (data not shown).

T3' and T4' in P3. Amino acid analysis (Table 3) showed that T3 and T4 of prealbumin are derived from residues $22-34$ and 22-35, respectively, and $\mathrm{T}^{\prime}$ ' and $\mathrm{T} 4^{\prime}$ only differ by containing one less valine and one methionine instead. Sequence analysis of $\mathrm{T}^{\prime}$ (each $1 \mathrm{nmol}$ ) from $\mathrm{P} 3$ of each of the 4 cases revealed the Val-Met replacement at residue 30 (Table 2).

The two major differences were further confirmed by isolation and analysis of 3 cyanogen bromide fragments of the P3 predominant protein from case 1 (Fig. 7 and Table 3). Fragment CB1 was eluted in two peaks from the HPLC column, probably because of homoserine and homoserine lactone forms. Although it was slightly heterogeneous, it was identified, by amino acid and sequence analysis, to derive mainly from residues 3-13 (Tables 2 and 3). Fragment CB2, also eluted in two peaks, was identified to be the peptide of residues 14-30 by composition, confirming the replacement of Val-Met at residue 30 in P3.

Further differences between prealbumin and P3 predominant protein were not 


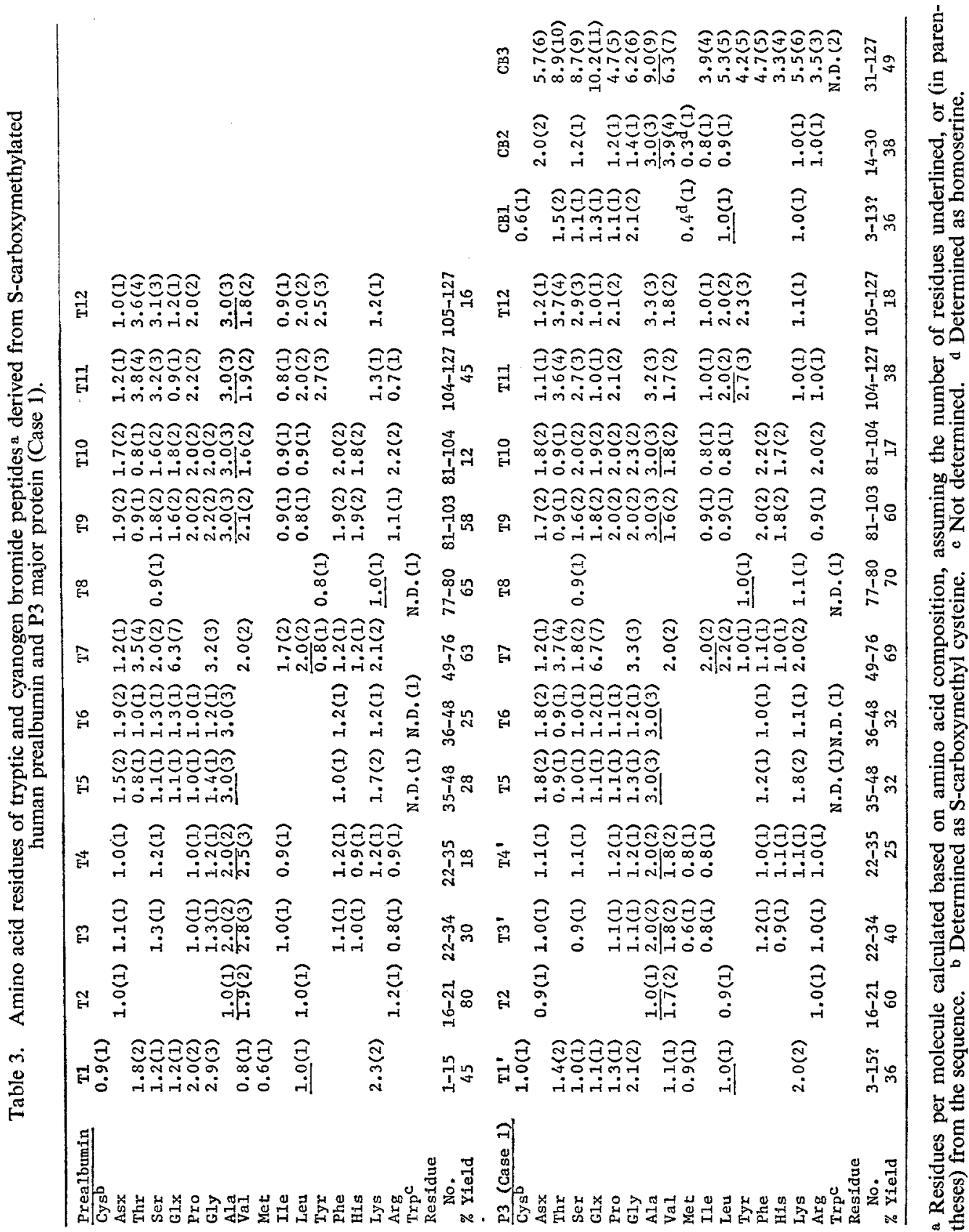

Vol. 29, No. 3, 1984 


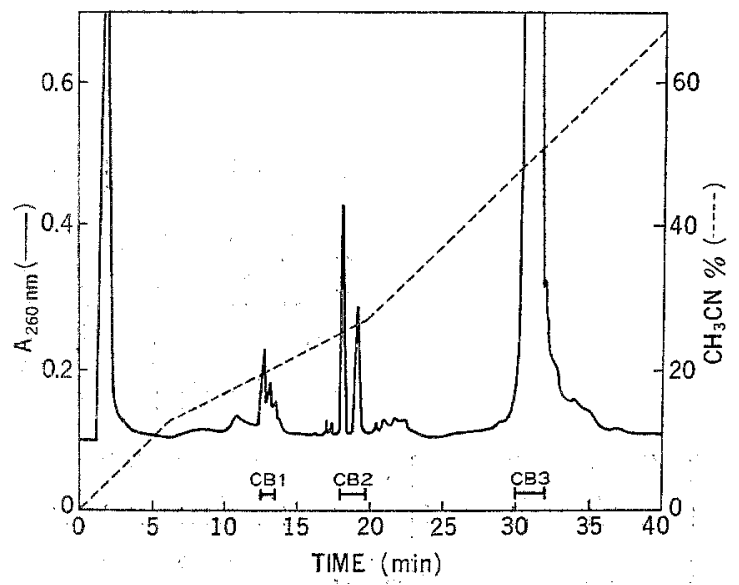

Fig. 7. Separation of the cyanogen bromide fragments of the $\mathrm{P} 3$ predominant protein (Case 1). 10 nmol of the protein was digested with cyanogen bromide as described in "Methods". The lyophilized digest was dissolved in $100 \mu \mathrm{l}$ of $6 \mathrm{M}$ $\mathrm{Gdn} \cdot \mathrm{HCl}$ and separated by reversed phase HPLC in a similar manner to that in Fig. 5.

explored in the present study, except for peptide $\mathrm{T} 7$ containing residue 49 , which might show a Thr-Gly replacement as in a variant reported by Pras et al. (1983), and residues 61 and 62 which had been identified to be Glx and Glx in a study of human prealbumin by Kanda et al. (1974). Sequence analysis of the peptide (1 nmol) revealed residue 49 as Thr and residues 61 through 63 as Glu-Glu-Glu, the last one of which differs from Gln-63 in prealbumin (Table 3).

All of other tryptic peptides are probably identical to those of prealbumin, because amino acid composition (Table 3 ) and elution position from HPLC (Fig. 6) were very similar to each other. The most probable sequence of the P3 predominant protein, which appears to be identical among the 4 cases, is shown in Fig. 8.

\section{DISCUSSION}

The present study on the primary structure of the amyloid fibril from Japanese patients with FAP confirmed the finding of Tawara et al. (1983) that this protein has the Val-Met replacement at residue 30 in prealbumin, and revealed another Gln-Glu replacement at residue 63 , which was recently found in the amyloid fibril of Swedish origin by Dwulet and Benson (1984). However, it is unknown whether the latter replacement indicates a real difference at the gene level between prealbumin and the P3 predominant protein, a specific deamidation of Gln-63 in P3 during isolation, or a misidentification of Glu-63 in the sequence analysis of prealbumin (Kanda et al., 1974). N-terminal heterogeneity is probably the result of proteolysis during amyloid formation or the isolation procedure. 


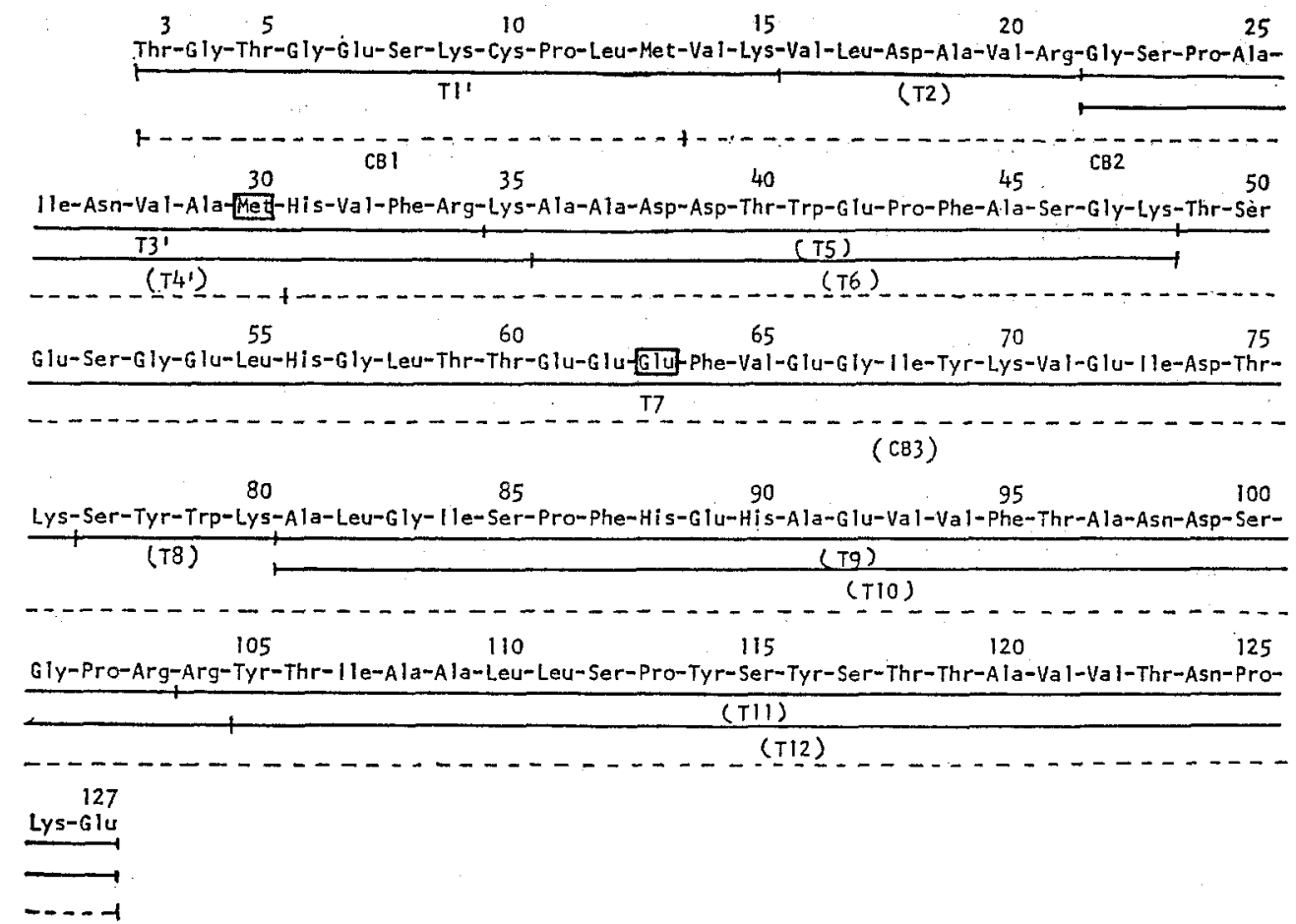

Fig. 8. Amino acid sequence of the P3 predominant protein ( 4 cases). The sequence shown herein was determined by sequence analysis of T1', T3', 'T7, and CB1, and by comparison of the tryptic peptides with those of human prealbumin of known primary sequence (Kanda et al., 1974). Peptides, of which the sequences were assumed to be identical to those of prealbumin, are shown in parentheses. Met and Glu (residues 30 and 63), which differ from Val and Gln in human prealbumin, are enclosed with a rectangle. The human prealbumin numbering system is used (Kanda et al., 1974).

The finding that the structural abnormality (prealbumin $30 \mathrm{Val} \rightarrow \mathrm{Met}$ ) was identical, irrespective of the subject or the family is particularly valuable from two genetic aspects. First, it supports our view that the families afflicted with FAP in Arao may have a common ancestor (Sakoda et al., 1984), although there are nine genealogically independent families (Sakoda et al., 1983). If we combine the findings presented in this report with information on the distribution of two rare variants, i.e. phosphoglucomutase 7 and group specific component J (Sakoda et al., 1984), we can conclude that five of the nine families have a common ancestor. Whether or not the FAP gene in the Arao focus is derived from the Protuguese reamins an interesting enigma (Andrade et al., 1970). Second, it lends credence to the view that the prealbumin variant is essentially concerned with the pathogenic mechanism of this genetically determined neuropathic disease. Although Tawara et al. (1983)

Vol, 29, No, 3, 1984 
reserved an alternative possibility-that this prealbumin variant is a polymorphism of prealbumin, the findings of this study make it unlikely.

Dwulet and Benson (1984) reported that normal and abnormal prealbumin are intermingled in the amyloid of FAP patients of Swedish origin. However, no normal prealbumin was present in any patient with FAP in Arao; the reason for this difference remains unknown.

Addendum Most recently, Saraiva et al. (1984) have reported that an abnormal prealbumin with a methionine for valine substitution at position 30 is present as amyloid protein in tissues and in plasma of Portuguese patients with FAP.

Acknowledgments We thank Dr. Yoshinao Wada and Dr. Kenneth A. Walsh for this encouragement and valuable discussions, Dr. Yoshikazu Kanda for providing pure human prealbumin, and Mr. Roger D. Wade and Mrs. Santosh Kumar for their skillful technical assistance. We are indebted to Prof. J. Miller, University of British Columbia, for looking over the manuscript.

This work has been supported in part by grants for Specific Diseases and for Monitoring Study of Congenital Disorders from the Ministry of Health and Welfare, Japan, and by grants from the National Institute of Health (GM 15731).

\section{REFERENCES}

Andersson, R. 1976. Familial amyloidosis with polyneuropathy. Acta Med. Scand. Suppl. 590: 1-64.

Andrade, C. 1952. A peculiar form of peripheral neuropathy: familial atypical generalized amyloidosis with special involvement of peripheral nerves. Brain 75: 408-417.

Andrade, C., Araki, S., Block, W.D., Cohen, A.S., Jackson, C.E., Kuroiwa, Y., McKusick, V.A., Nissim, J., Sohar, E., and Van Allen, M.W. 1970. Hereditary amyloidosis. Arthr. Rheum. 13: $902-915$.

Araki, S., Mawatari, S., Ohta, M., Nakajima, A., and Kuroiwa, Y. 1968. Polyneuritic amyloidosis in a Japanese family. Arch. Neurol. 18: 593-602.

Benson, M.D. 1981. Partial amino acid sequence homology between an heredofamilial amyloid protein and human plasma prealbumin. J. Clin. Invest. 67: 1035-1041.

Costa, P.P., Figueira, A.S., and Bravo, F.R. 1978. Amyloid fibril protein related to prealbumin in familial amyloidotic polyneuropathy. Proc. Natl. Acad. Sci. U.S.A. 75: 4499-4503.

Crestfield, A.M., Moore, S., and Stein, W.H. 1963. The preparation and enzymatic hydrolysis of reduced and S-carboxymethylated proteins. J. Biol. Chem. 238: 622-627.

Dwulet, F.E. and Benson, M.D. 1983. Polymorphism of human plasma thyroxine binding prealbumin. Biochem. Biophys. Res. Commun. 114: 657-662.

Dwulet, F.E. and Benson, M.D. 1984. Primary structure of an amyloid prealbumin and its plasma precursor in a heredofamilial polyneuropathy of Swedish origin. Proc. Natl. Acad. Sci. U.S.A. 81: 694-698.

Glenner, G.G., Harada, M., and Isersky, C. 1972. The purification of amyloid fibril proteins. Prep. Biochem. 2: 39-51.

Glenner, G.G., Ignaczak, T.F., and Page, D.L. 1978. The inherited systemic amyloidoses and localized amyloid deposits. In The Metabolic Basis of Inherited Disease, Stanbury, J.B., Wyngaarden, J.B., and Fredrickson, D.S., eds., 4th ed., McGraw-Hill Book Company, New York, pp. 1308-1339.

Gonzalez, G. and Offord, R.E. 1971. The subunit structure of prealbumin. Biochem. J. 125: 309317. 
Gross, E. 1967. The cyanogen bromide reaction. Methods Enzymol. XI: 238-255.

Hunkapiller, M.W., Hewick, R.M., Dryer, W.J., and Hood, L.E. 1983a. High-sensitivity sequencing with a gas-phase sequenator. Methods Enzymol. 91: 399-413.

Hunkapiller, M.W. and Hood, L.E. 1983b. Analysis of phenylthiohydantoins by ultrasensitive gradient high-performance liquid chromatography. Methods Enzymol. 91: 486-493.

Kanda, Y., Goodman, D.S., Canfield, R.E., and Morgan, F.J. 1974. The amino acid sequence of human plasma prealbumin. J. Biol. Chem. 249: 6796-6805.

Kito, S., Fujimori, N., Yamamoto, M., Itoga, E., Toyoizumi, Y., Kakizaki, T., Mitsui, Z., Ichikawa, H., Morinaga, T., Wakatsuki, K., Satoh, S., and Iwasaki, I. 1973. A focus of familial amyloid polyneuropathy. Nippon Rinsho 31: 2326-2388 (in Japanese).

Mahoney, W.C. and Hermodson, M.A. 1980. Separation of large denatured peptides by reverse phase high performance liquid chromatography. J. Biol. Chem. 255: 11199-11203.

Pras, M., Shubert, M., Zucker-Franklin, D., Rimon, A., and Franklin, E.C. 1968. The characterization of soluble amyloid prepared in water. J. Clin. Invest. 47: 924-933.

Pras, M., Prelli, F., Franklin, E.C., and Frangione, B. 1983. Primary structure of an amyloid prealbumin variant in familial polyneuropathy of Jewish origin. Proc. Natl. Acad. Sci. U.S.A. 80: $539-542$.

Righetti, P.G. and Chillemi, F. 1978. Isoelectric focusing of peptides. J. Chromatogr. 157: 243251.

Sakoda, S., Suzuki, T., Higa, S., Ueji, M., Kishimoto, S., Hayashi, A., Yasuda, N., Takaba, Y., and Nakajima, A. 1983. The genetic studies of familial amyloid polyneuropathy in the Arao district of Japan: I. The genealogical survey. Clin. Genet. 24: 334-338.

Sakoda, S., Suzuki, T., Higa, S., Ueji, M., Kishimoto, S., Wada, Y., Hayashi, A., Matsumoto, H., Miyazaki, T., Sasazuki, T., Nishimura, K., Egami, M., Omoto, K., Tokunaga, K., Takaba, Y., and Nakajima, A. 1984. The genetic studies of familial amyloid polyneuropathy in the Arao district of Japan. II. Studies of genetic markers in blood. Jpn. J. Human Genet. 29: 51-57.

Saraiva, M.J.M., Birken, S., Costa, P.P., and Goodman, D.S. 1984. Amyloid fibril protein in familial amyloidotic polyneuropathy, Portuguese type. Definition of molecular abnormality in transthyretin (prealbumin). J. Clin. Invest. 74: 104-119.

Shoji, S. and Okano, A. 1981. Amyloid fibril protein in familial amyloid polyneuropathy. Neurology 31: 186-190.

Skinner, M. and Cohen, A.S. 1981. The prealbumin nature of the amyloid protein in familial amyloid polyneuropathy (FAP)-Swedish variety. Biochem. Biophys. Res. Commun. 99: 13261332.

Tawara, S., Araki, S., Toshimori, K., Nakagawa, H., and Ohtaki, S. 1981. Amyloid fibril protein in type I familial amyloidotic polyneuropathy in Japanese. J. Lab. Clin. Med. 98: 811-822.

Tawara, S., Nakazato, M., Kangawa, K., Matsuo, H., and Araki, S. 1983. Identification of amyloid prealbumin variant in familial amyloidotic polyneuropathy (Japanese type). Biochem. Biophys. Res. Commun. 116: 880-888.

Weber, K. and Osborn, M. 1969. The reliability of molecular weight determinations by dodecyl sulfate polyacrylamide gel electrophoresis. J. Biol. Chem. 244: 4406-4412. 